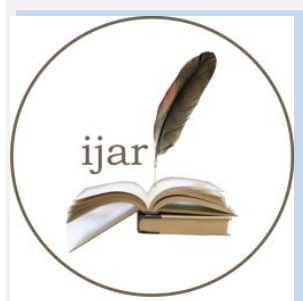

ISSN NO. 2320-5407 \section{INTERNATIONAL JOURNAL OF ADVANCED RESEARCH (IJAR)}

Journal Homepage: - www.journalijar.com

Article DOI: $10.21474 / \mathrm{IJAR} 01 / 1311$

DOI URL: http://dx.doi.org/10.21474/IJAR01/1311
INTERNATIONAL JOURNAL OF ADVANCED RESEARCH (JJAR)

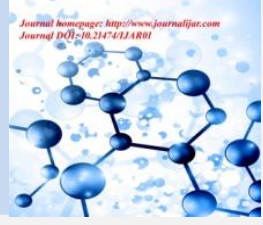

RESEARCH ARTICLE

\title{
DEVELOPMENT OF MULTIGRAINS FLOUR PIZZA BASE FOR VALUE ADDITION.
}

\author{
"Anu Agrawal ${ }^{1}$ and Anisha Verma ${ }^{2}$. \\ 1. Research Scholar, Department of Foods and Nutrition, SHIATS, Allahabad, U.P. \\ 2. Assistant Professor, Department of Foods and Nutrition, SHIATS, Allahabad, U.P.
}

\section{Manuscript Info}

Manuscript History

Received: 16 June 2016

Final Accepted: 18 July 2016

Published: August 2016

Key words:-

Multigrain, Pizza Base, sensory

acceptability and nutritionally rich.

\begin{abstract}
The consumption of course grains and millets decreased incidence of diabetes, C.V.D, cancers and obesity which are increasing in an exponential manner globally and to combat them, a raise in demand for food containing complex carbohydrates with higher levels of dietary fibre and health beneficial photochemical has been in demand. The aim of the study was to develop the multigrain flour product, to check the sensory acceptability of the product, to calculate the nutritive. Multigrain flour was prepared by mixing of five flours in four different ratios (finger millets, oat, buck wheat and pearl millets) named as $T_{1}, T_{2}, T_{3}$ and $T_{4}$. Pizza Base prepared from the wheat flour only served as control $\left(\mathrm{T}_{0}\right)$. The product was organoleptically evaluated by Nine Point Hedonic Scale. The nutritional composition of product was chemically analyzed by using the AOAC (2005) methods. Appropriate statistical technique was opted for the analysis. On the basis of sensory evaluation $\mathrm{T}_{4}$ (20:25:20:20:15) was most acceptable with regards to all sensory parameters. There was a significant difference between the sensory attributes of different treatments at $5 \%$ significance level. The proximate compositions of developed Pizza Base were $23.23 \mathrm{~g}$ moisture, $10.23 \mathrm{~g}$ fiber, $19.47 \mathrm{~g}$ protein, $7.38 \mathrm{~g}$ fat, 108.32 carbohydrates and $501.33 \mathrm{kcal}$ energy.The mineral contents $462.95 \mathrm{mg}$ calcium, $20.88 \mathrm{mg}$ iron and $579.90 \mathrm{mg}$ phosphorus. Therefore it can be concluded that the product of multigrain are more beneficial than normal Pizza Base.
\end{abstract}

Copy Right, IJAR, 2016,. All rights reserved.

\section{Introduction:-}

Coarse grains and small millets like (finger millets, oat, buck wheat and pearl millets) having the anti microbial, anti oxidant properties. The incidence of diabetes and obesity are increasing in an exponential manner globally and to combat them, a raise in demand for food containing complex carbohydrates with higher levels of dietary fibre and health beneficial phytochemicals has been in demand. Fortification of diets with food materials rich in phenolic acids was shown to impart antimutagenic, antiglycemic, and antioxidative properties, and this can be exploited in developing health foods.

Oats are the seeds of the plant Avena sativa, as a dermatological agent colloidal extracts of oats have been used for their antioxidant, anti-inflammatory, moisturizing, cleansing and even ultraviolet protective properties. Nutritionally

Corresponding Author:- Anu Agrawal.

Address:- Research Scholar, Department of Foods and Nutrition, SHIATS, Allahabad, U.P. 
oats are an excellent source of soluble fiber in the form of beta-glucans, alpha tocopherols, B vitamins, minerals, proteins, and plant fats. Their ability to lower serum cholesterol levels. Oat beta glucan isolates have been shown to shift serum cholesterol profiles to contain less LDL and more of the desired HDL. Oat bran products have been shown to reduce postprandial glucose spike after a glucose load in patients with type II diabetes. Pearl millet has been recommended for several therapeutic purposes, as it has been found to inhibit tumour development, control blood pressure and plasma low density lipo protein cholesterol levels, and possesses anti-allergenic characteristics. Buckwheat flour may alleviate diabetes, obesity, hypertension, and hypercholesterolemia. Buckwheat grains are an important source of microelements, such as: $\mathrm{Zn}, \mathrm{Cu}, \mathrm{Mn}$, Se and macro elements: $\mathrm{K}, \mathrm{Na}, \mathrm{Ca}, \mathrm{Mg}$ (Wei et al. 2003) also contains vitamins: B1, B2, and B6 (Fabjan et al. 2003) with $80 \%$ unsaturated fatty acids more than $40 \%$ are constituted by polyunsaturated fatty acid (PUFA) (Krkoskova And Mrazova, 2005). Finger millet contains about 5-8\% protein, 1-2\% ether extractives, 65-75\% carbohydrates, 15-20\% dietary fiber and 2.5-3.5\% minerals (Chethan and Malleshi, 2007). It has the highest calcium content among all cereals (344 mg/100 g). However, the millet also contains phytates $(0.48 \%)$, polyphenols, tannins $(0.61 \%)$, trypsin inhibitory factors, and dietary fiber, which were once considered as "anti nutrients" due to their metal chelating and enzyme inhibition activities (Thompson, 1993).

\section{Material \& method:-}

\section{Raw material:-}

Basic ingredients for Pizza Base preparation were purchased from the local market of Allahabad.

\section{Development of Multigrain Flour Mixture:-}

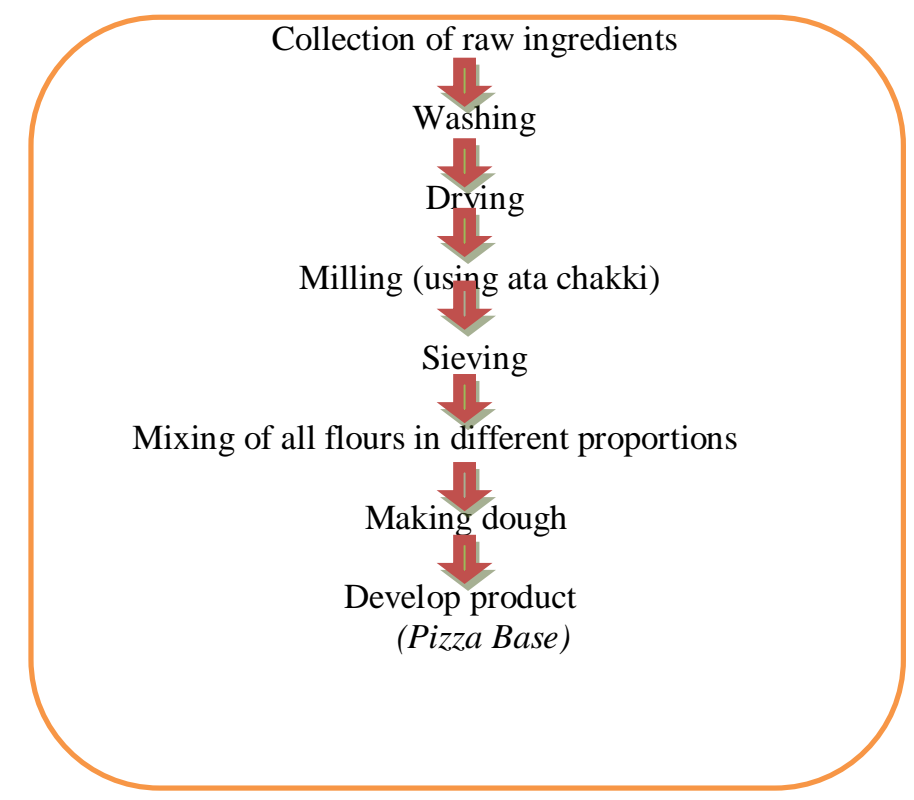

Figure 1.0:- Preparation of Multigrain Flour.

Source- Manay and swamy (2001) Food Facts and Principles, II $^{\text {nd }}$ Edition

\section{Development of the product:-}

Table 1.0 shows the data of value added product Pizza Base were developed by using multigrain flour mixture. The basic recipe were standardized and served control $\left(\mathrm{T}_{0}\right)$.

\begin{tabular}{|l|l|l|l|l|l|}
\hline $\begin{array}{l}\text { Treatments } \\
\text { Products }\end{array}$ & $\begin{array}{l}\mathrm{T}_{0} \\
(\%)\end{array}$ & $\begin{array}{l}\mathrm{T}_{1} \\
(\%)\end{array}$ & $\begin{array}{l}\mathrm{T}_{2} \\
(\%)\end{array}$ & $\begin{array}{l}\mathrm{T}_{3} \\
(\%)\end{array}$ & $\begin{array}{l}\mathrm{T}_{4} \\
(\%)\end{array}$ \\
\hline Wheat & 100 & 35 & 30 & 25 & 20 \\
\hline Oats & - & 10 & 20 & 15 & 25 \\
\hline Finger millets & - & 20 & 15 & 15 & 20 \\
\hline Pearl millets & - & 20 & 15 & 25 & 20 \\
\hline Buckwheat & - & 15 & 20 & 20 & 15 \\
\hline
\end{tabular}




\section{Organoleptic analysis of developed food products:-}

Prepared products were freshly served to taste panel of 4(four) experienced Panel members. were rated the product with the help of nine points hedonic scale.

\section{Statistical analysis:-}

All analysis was done by applying two way classification and analysis of variance techniques.

\section{Results and discussion:-}

Figre 2.0:- Average sensory score of different parameters in control and treated sample of Multigrain Flour Pizza Base.

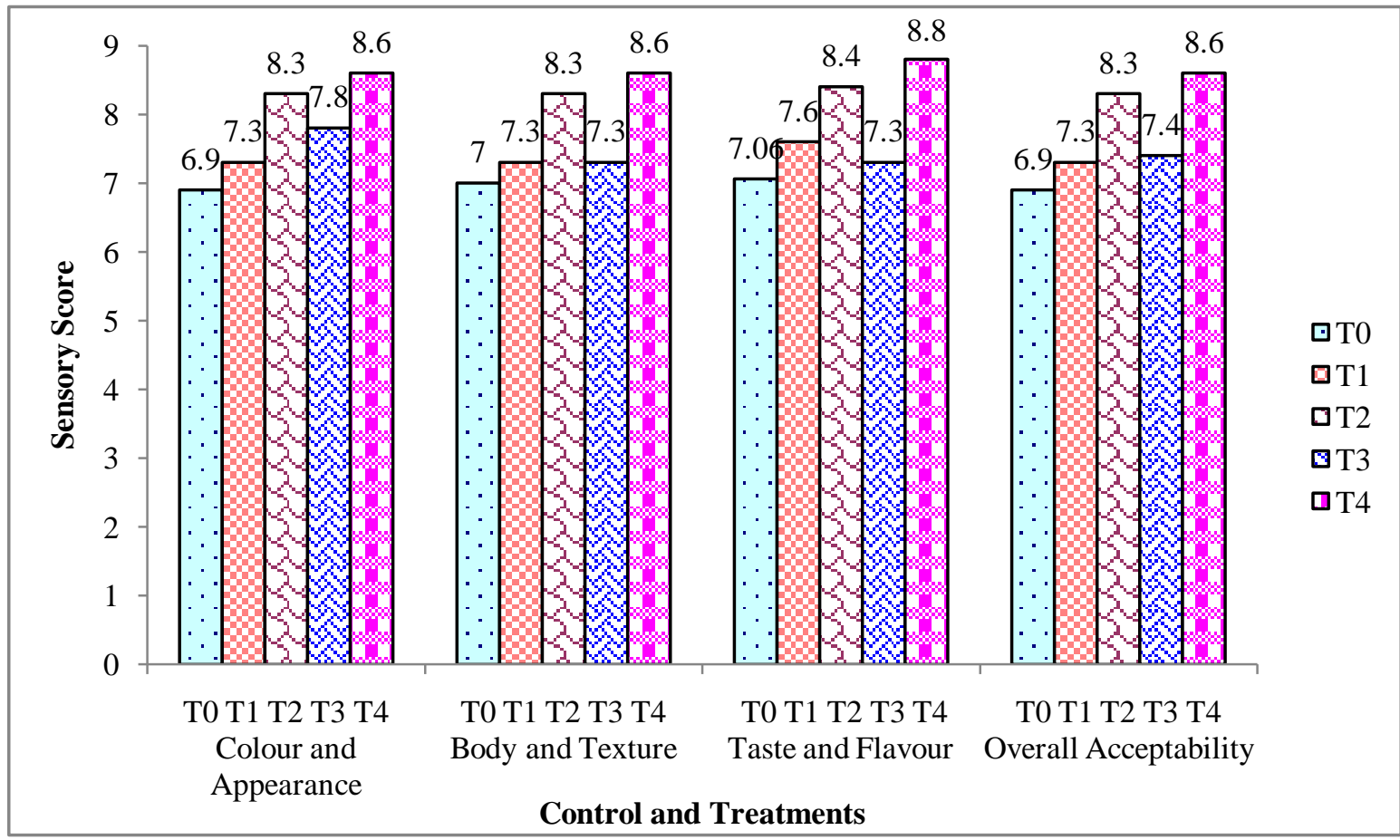

Figure 2.0 shows the mean scores of Multigrain Flour Pizza Base in relation to colour and appearance, which indicates that treatment $\mathrm{T}_{4}(8.6)$ had the highest mean score followed by Treatments $\mathrm{T}_{2}(8.3), \mathrm{T}_{3}(7.8), \mathrm{T}_{1}(7.3)$ and $\mathrm{T}_{0}$ (6.9). The mean scores of Multigrain Flour Pizza Base in relation to body and texture, which indicates that treatment $\mathrm{T}_{4}$ (8.6) had the highest mean score followed by Treatments $\mathrm{T}_{2}(8.3), \mathrm{T}_{3}(7.3), \mathrm{T}_{1}$ (7.3) and $\mathrm{T}_{0}(7.0)$. The mean scores of Multigrain Flour Pizza Base in relation to taste and flavor, which indicates that treatment $\mathrm{T}_{4}(8.8)$ had the highest mean score followed by Treatments $T_{2}(8.4), T_{1}$ (7.6), $T_{1}$ (7.3) and $T_{0}$ (7.06). The mean scores of Multigrain Flour Pizza Base in relation to overall acceptability, which indicates that treatment $\mathrm{T}_{4}(8.6)$ had the highest mean score followed by Treatments $\mathrm{T}_{2}(8.3), \mathrm{T}_{3}(7.4), \mathrm{T}_{1}$ (7.3) and $\mathrm{T}_{0}(6.9)$.

Table 2.0:- Analysis of variance all sensory parameters of Multigrain flour Pizza Base

\begin{tabular}{|c|c|c|c|}
\hline \multicolumn{4}{|c|}{ Analysis of variance data of sensory attributes } \\
\hline & F-Cal & F-tab & Result \\
\hline Colour and Appearance & 31.2 & 3.82 & $\mathrm{~S}$ \\
& 4.8 & 4.45 & $\mathrm{~S}$ \\
\hline Body and Texture & 37.12 & 3.82 & $\mathrm{~S}$ \\
\hline & 0.95 & 4.45 & $\mathrm{~N}$ \\
\hline Taste and Flavour & 54.33 & 3.82 & $\mathrm{~S}$ \\
\hline Overall Accptability & 0.16 & 4.45 & $\mathrm{~S}$ \\
\cline { 2 - 4 } & 29.95 & 3.82 & $\mathrm{~S}$ \\
\hline & 5.6 & 4.45 & $\mathrm{~S}$ \\
\hline
\end{tabular}

S = Significant, NS = Non Significant 
The ANOVA table 2.0 shows that the calculated value of F (31.2) was greater than table value of F (3.82) at 5\% probability level. This shows there is significant difference between the control and treatments regarding colour and appearance. It indicates that the colour and appearance of prepared Multigrain Flour Pizza Base was increased due to addition of different proportions, which may be ascribed to different rations of multigrain flour mixture and calculated value of F (37.12) was greater than table value of F (3.82) at 5\% probability level. This shows there is significant difference between the control and treatments regarding body and texture. It indicates that the Body and Texture of prepared Multigrain Flour Pizza Base was increased due to addition of different proportions, which may be ascribed to different rations of multigrain flour mixture. Regarding Taste and Flavor the calculated value of $\mathrm{F}$ (54.33) was greater than table value of F (3.82) at 5\% probability level. This shows there is significant difference between the control and treatments regarding taste and flavor. It indicates that the Taste and Flavor of prepared Multigrain Flour Pizza Base was increased due to addition of different proportions, which may be ascribed to different rations of multigrain flour mixture.

The given table also indicates the calculated value of F (29.95) was greater than table value of $\mathrm{F}(3.82)$ at $5 \%$ probability level. This shows there is significant difference between the control and treatments regarding overall acceptability. It indicates that the overall acceptability of prepared Multigrain Flour Pizza Base was increased due to addition of different proportions, which may be ascribed to different rations of multigrain flour mixture.

Table 3.0:- Comparison of Colour and Appearance of Pizza Base with multigrain flour mixture against critical difference

\begin{tabular}{|c|c|c|c|c|}
\hline \multicolumn{5}{|c|}{ Colour and Appearance of Pizza Base } \\
\hline $\begin{array}{l}\text { Treatment and } \\
\text { mean values }\end{array}$ & $\mathrm{T}_{4}(8.6)$ & $\mathrm{T}_{2}(8.3)$ & $\mathrm{T}_{3}(7.8)$ & $\mathrm{T}_{1}(7.3)$ \\
\hline $\mathrm{T}_{0}(6.9)$ & $1.7^{\mathrm{S}}$ & $1.4^{\mathrm{S}}$ & $0.9^{\mathrm{S}}$ & $0.4^{\mathrm{S}}$ \\
\hline $\mathrm{T}_{1}(7.3)$ & $1.3^{\mathrm{S}}$ & $1.0^{\mathrm{S}}$ & $0.5^{\mathrm{S}}$ & - \\
\hline $\mathrm{T}_{3}(7.8)$ & $0.8^{\mathrm{S}}$ & $0.5^{\mathrm{S}}$ & - & - \\
\hline $\mathrm{T}_{2}(8.3)$ & $0.3^{\mathrm{S}}$ & - & - & - \\
\hline \multicolumn{5}{|c|}{$\mathrm{CD}=0.29, \mathrm{~S}=$ Significant } \\
\hline \multicolumn{5}{|c|}{ Body and Texture of Pizza Base } \\
\hline $\begin{array}{l}\text { Treatment and } \\
\text { mean values }\end{array}$ & $\mathrm{T}_{4}(8.6)$ & $\mathrm{T}_{2}(8.3)$ & $\mathrm{T}_{1}(7.3)$ & $\mathrm{T}_{3}(7.3)$ \\
\hline $\mathrm{T}_{0}(7.0)$ & $1.6^{\mathrm{S}}$ & $1.3^{\mathrm{S}}$ & $0.3^{\mathrm{S}}$ & $0.3^{\mathrm{S}}$ \\
\hline $\mathrm{T}_{3}(7.3)$ & $1.3^{\mathrm{S}}$ & $1.0^{\mathrm{S}}$ & - & - \\
\hline $\mathrm{T}_{1}(7.3)$ & $1.3^{\mathrm{S}}$ & $1.0^{\mathrm{S}}$ & - & - \\
\hline $\mathrm{T}_{2}(8.3)$ & $0.3^{\mathrm{S}}$ & - & - & - \\
\hline \multicolumn{5}{|c|}{$\mathrm{CD}=0.26, \mathrm{~S}=$ Significant } \\
\hline \multicolumn{5}{|c|}{ Taste and Flavour of Pizza Base } \\
\hline $\begin{array}{c}\text { Treatment and } \\
\text { mean values }\end{array}$ & $\mathrm{T}_{4}(8.8)$ & $\mathrm{T}_{2}(8.4)$ & $\mathrm{T}_{1}(7.6)$ & $\mathrm{T}_{3}(7.3)$ \\
\hline $\mathrm{T}_{0}(7.06)$ & $1.7^{\mathrm{S}}$ & $1.3^{\mathrm{S}}$ & $0.5^{\mathrm{S}}$ & $0.24^{\mathrm{S}}$ \\
\hline $\mathrm{T}_{3}(7.3)$ & $1.5^{\mathrm{S}}$ & $1.1^{\mathrm{S}}$ & $0.3^{\mathrm{S}}$ & - \\
\hline $\mathrm{T}_{1}(7.6)$ & $1.2^{\mathrm{S}}$ & $0.8^{\mathrm{S}}$ & - & - \\
\hline $\mathrm{T}_{2}(8.4)$ & $0.4^{\mathrm{S}}$ & - & - & - \\
\hline \multicolumn{5}{|c|}{$\mathrm{CD}=0.23, \mathrm{~S}=$ Significant } \\
\hline \multicolumn{5}{|c|}{ Overall Acceptability of Pizza Base } \\
\hline $\begin{array}{l}\text { Treatment and } \\
\text { mean values }\end{array}$ & $\mathrm{T}_{4}(8.6)$ & $\mathrm{T}_{2}(8.3)$ & $\mathrm{T}_{3}(7.4)$ & $\mathrm{T}_{1}(7.3)$ \\
\hline $\mathrm{T}_{0}(6.9)$ & $1.7^{\mathrm{S}}$ & $1.4^{\mathrm{S}}$ & $0.5^{\mathrm{S}}$ & $0.4^{\mathrm{S}}$ \\
\hline $\mathrm{T}_{1}(7.3)$ & $1.3^{\mathrm{S}}$ & $1.6^{\mathrm{S}}$ & $0.1^{\mathrm{NS}}$ & - \\
\hline $\mathrm{T}_{3}(7.4)$ & $1.2^{\mathrm{S}}$ & $0.9^{\mathrm{S}}$ & - & - \\
\hline $\mathrm{T}_{2}(8.3)$ & $0.3^{\mathrm{S}}$ & - & - & - \\
\hline
\end{tabular}


Table 3.0 reveals the difference between the mean values of colour and appearance $\mathrm{T}_{0}, \mathrm{~T}_{4}(1.7) ; \mathrm{T}_{0}, \mathrm{~T}_{2}(1.4) ; \mathrm{T}_{0}, \mathrm{~T}_{3}$ (0.9); $\mathrm{T}_{0}, \mathrm{~T}_{1}(0.4) ; \mathrm{T}_{1}, \mathrm{~T}_{4}(1.3) ; \mathrm{T}_{1}, \mathrm{~T}_{2}(1.0) ; \mathrm{T}_{1}, \mathrm{~T}_{3}(0.5) ; \mathrm{T}_{3}, \mathrm{~T}_{4}(0.8) ; \mathrm{T}_{3}, \mathrm{~T}_{2}(0.5) ; \mathrm{T}_{2}, \mathrm{~T}_{4}(0.3)$; were greater than the $\mathrm{CD},(0.29)$ therefore the difference was significant.

The difference between the mean values of body and texture $\mathrm{T}_{0}, \mathrm{~T}_{4}(1.6) ; \mathrm{T}_{0}, \mathrm{~T}_{2}(1.3) ; \mathrm{T}_{0}, \mathrm{~T}_{1}(0.3) ; \mathrm{T}_{0}, \mathrm{~T}_{3}(0.3)$; $\mathrm{T}_{3}, \mathrm{~T}_{4}$ (1.3); $\mathrm{T}_{3}, \mathrm{~T}_{2}(1.0) ; \mathrm{T}_{1}, \mathrm{~T}_{4}(1.3) \mathrm{T}_{1}, \mathrm{~T}_{2}(1.0) ; \mathrm{T}_{2}, \mathrm{~T}_{4}(0.3)$; were greater than the $\mathrm{CD},(0.26)$ therefore the difference was significant.

The difference between the mean values of taste and flavour $\mathrm{T}_{0}, \mathrm{~T}_{4}(1.7) ; \mathrm{T}_{0}, \mathrm{~T}_{2}(1.3) ; \mathrm{T}_{0}, \mathrm{~T}_{1}(0.5) ; \mathrm{T}_{0}, \mathrm{~T}_{3}(0.24) ; \mathrm{T}_{3}$, $\mathrm{T}_{4}(1.5) ; \mathrm{T}_{3}, \mathrm{~T}_{2}(1.1) ; \mathrm{T}_{3}, \mathrm{~T}_{1}(0.3) ; \mathrm{T}_{1}, \mathrm{~T}_{4}(1.2) ; \mathrm{T}_{1}, \mathrm{~T}_{2}(0.8) ; \mathrm{T}_{2}, \mathrm{~T}_{4}(0.4)$; were greater than the $\mathrm{CD}$, $(0.23)$ therefore the difference was significant.

The difference between the mean values of overall acceptability $\mathrm{T}_{0}, \mathrm{~T}_{4}(1.7) ; \mathrm{T}_{0}, \mathrm{~T}_{2}(1.4) ; \mathrm{T}_{0}, \mathrm{~T}_{3}(0.5) ; \mathrm{T}_{0}, \mathrm{~T}_{1}(0.4) ; \mathrm{T}_{1}$, $\mathrm{T}_{4}(1.3) ; \mathrm{T}_{1}, \mathrm{~T}_{2}(1.6) ; \mathrm{T}_{3}, \mathrm{~T}_{4}(1.2) ; \mathrm{T}_{3}, \mathrm{~T}_{2}(0.9) ; \mathrm{T}_{2}, \mathrm{~T}_{4}(0.3)$; were greater than the $\mathrm{CD},(0.29)$ therefore the difference was significant.

The difference between the mean values $\mathrm{T}_{1}, \mathrm{~T}_{3}(0.1)$; were less than the $\mathrm{CD},(0.29)$ therefore the difference was nonsignificant.

It is therefore concluded that the average score of overall acceptability of Pizza Base has significant difference, which may be ascribed to different rations of multigrain flour mixture.

Table 4.0:- Comparison between nutrient contents of control and treatment of Multigrain Flour Pizza Base using ttest.

\begin{tabular}{|c|c|c|c|c|c|c|}
\hline Nutrients & $\mathrm{T}_{0}$ & $\mathrm{~T}_{4}$ & $\begin{array}{l}\text { Difference } \\
\left(\mathrm{T}_{0}-\mathrm{T}_{4}=\mathrm{D}\right)\end{array}$ & $\mathrm{t}$ (calculated) & $\begin{array}{c}\mathrm{T} \text { (tabulated } \\
\text { value at } 5 \% \text { ) }\end{array}$ & Results \\
\hline Moisture (g) & 14.67 & 23.23 & 8.56 & 6.43 & 2.45 & $\mathrm{~S}$ \\
\hline Fiber $(\mathrm{g})$ & 3.32 & 12.43 & 9.11 & 6.23 & 2.45 & $\mathrm{~S}$ \\
\hline Protein $(\mathrm{g})$ & 8.89 & 19.47 & 10.58 & 5.65 & 2.45 & $\mathrm{~S}$ \\
\hline Fat $(\mathrm{g})$ & 4.24 & 12.39 & 8.15 & 4.96 & 2.45 & $\mathrm{~S}$ \\
\hline Carbohydrate (g) & 70.12 & 115.54 & 45.42 & 11.70 & 2.45 & $\mathrm{~S}$ \\
\hline Energy(Kcal) & 382.12 & 532.47 & 141.35 & 20.60 & 2.45 & $\mathrm{~S}$ \\
\hline Calcium (mg) & 47.13 & 462.95 & 415.82 & 35.35 & 2.45 & $\mathrm{~S}$ \\
\hline Iron (mg) & 7.09 & 25.47 & 16.38 & 7.03 & 2.45 & $\mathrm{~S}$ \\
\hline Phosphorus (mg) & 372.0 & 579.90 & 207.9 & 24.98 & 2.45 & $\mathrm{~S}$ \\
\hline
\end{tabular}

\section{$\mathrm{S}=$ Significance; NS = Non-Significance}

Table 4.0 shows Significance difference between control and best treatment regarding their Fiber (g), Protein (g), Fat (g), Carbohydrate (g), Energy (Kcal), Calcium (mg), Iron (mg), Phosphorus (mg) and TPC ( $\mu$ g/glc acid) as the calculated value of ' $\mathrm{t}$ ' found greater than the ' $\mathrm{t}$ ' tabulated value i.e. 2.45 at 5 percent probability level and therefore there were significance difference between control and best treatment $\left(\mathrm{T}_{4}\right)$ of Multigrain Flour Pizza Base.

The result is supported by the findings of Andersson et al. (2014) also reported the increment of the values of bioactive components in the developed cereal products

\section{Conclusion:-}

From the results presented of the study it can be concluded that developed value added product (multigrain pizza base) were richer in carbohydrate, protein, fat, fiber, iron, calcium and phosphorus. Therefore, it will be helpful to improve the nutritional status of the population by including one serving of multigrain with our routine diet and decrease chances of nutrient deficiency diseases. 


\section{References:-}

1. Andersson Annica A.M., Lena Dimberg, Per Åman, Rikard Landberg (2014) Recent findings on certain bioactive components in whole grain wheat and rye, Journal of Cereal Science, volume 59-pp294-311.

2. AOAC. (2005) Handbook of analysis and quality control for fruit and vegetable products; Tata McGraw Hill Education PVT.LTD. edition $2^{\text {nd }}$, pp 18-22.

3. Chethan S, Malleshi NG (2007) Finger millet polyphenols: characterization and their nutraceutical potential. American Journal of Food Technology, volume 2, pp582-592.

4. Fabjan N., Rode J., Kosir I.J., Zhang Z., Kreft I. (2003) Tatary buckwheat (Fagopyrum tartaricum Gaertn.) as a source of dietary rutin and quercetin, Journal of Agricultural and Food Chemistry, volume 51, pp 64526455 .

5. Krkoskova B., Mrazova Z. (2005) Prophylactic components of buckwheat, International Journal of Food Research, volume 38, pp561-568.

6. Manay Shakuntala and swamy Shadakshara (2001) Glycemic index of oat incorporated with wheat, International Journal of Food Facts and Principles, volume 5, edition $2^{\text {nd }}$, pp 166-175.

7. Thompson LU (1993) Potential health benefits and problems associated with anti nutrients in foods, International Journal of Food Research, volume 26, pp 131-149.

8. Wei Y., Hu X., Zhang G., Ouyang S. (2003) Studies on the amino acid and mineral content of buckwheat protein fractions. Czech Journal Food Science, volume 47, pp 114-116. 